\title{
Investigation on the Performance of an Organic Solar Cell by the Modification of Cathode with Lanthanum Fluoride Thin Layer
}

\author{
Md. Shahinul Islam ${ }^{1}$, Golam Saklayen ${ }^{1}$, Hartmut Baerwolff $^{\mathbf{2}}$, Abu Bakar Md. Ismail ${ }^{1}$ \\ ${ }^{1}$ Department of Applied Physics \& Electronic Engineering, Rajshahi University, Rajshahi, Bangladesh \\ ${ }^{2}$ Department of Analog \& Optoelectronics, Cologne University of Applied Sciences, Germany
}

Email address:

shahinulislamrony@gmail.com (Md. Shahinul Islam)

\section{To cite this article:}

Md. Shahinul Islam, Golam Saklayen, Hartmut Baerwolff, Abu Bakar Md. Ismail. Investigation on the Performance of an Organic Solar Cell by the Modification of Cathode with Lanthanum Fluoride Thin Layer. American Journal of Modern Physics. Vol. 4, No. 6, 2015 , pp. 274-280. doi: $10.11648 /$ j.ajmp.20150406.13

\begin{abstract}
Performance of organic solar cell (OSC) using the modification of cathode has been investigated in this research. OSC has been fabricated using the blend of P3HT (poly (3-hexylthiophene)) and PCBM (Phenyl C61 butyric acid methylester) at 1:1 ratio. E-beam evaporated indium tin oxide (ITO) has been used as the anode. A novel bi-layer of e-beam-evaporated $\mathrm{LaF}_{3}$ and $\mathrm{Al}$ $\left(\mathrm{LaF}_{3} / \mathrm{Al}\right)$ has been used as the cathode. The morphology of the ITO, P3HT: PCBM and $\mathrm{LaF}_{3}$ layer has been investigated by Atomic Force Microscope (AFM). $\mathrm{LaF}_{3}$ layer between P3HT: PCBM and Al layer was found to influence the reverse current, open-circuit voltage and efficiency of OSC. Various thicknesses of $\mathrm{LaF}_{3}$ layer have been investigated, and $3 \mathrm{~nm}$ thick $\mathrm{LaF}_{3}$ layer was found to be the optimum thickness for the enhancement of the various solar-cell parameters of our fabricated OSC. The effect of annealing on the performance of the cell has been also investigated. The post-fabrication annealed devices, with or without the $\mathrm{LaF}_{3}$ layer, exhibited higher values of short-circuit current, open-circuit voltage than those of similar devices annealed before depositing the $\mathrm{Al}$ metal. It was found that annealing at $150^{\circ} \mathrm{C}$ for 20 minutes provided the best result. The overall power conversion efficiency was found to enhance several times than that of the conventional structure of OSC having only $\mathrm{Al}$ as the cathode. Altogether the experimental results show that bi-layer of $\mathrm{LaF}_{3} / \mathrm{Al}$ cathode could enhance the overall performance of OSC.
\end{abstract}

Keywords: Organic Solar Cell, P3HT: PCBM Polymer Photoactive Layer, Annealing, Bi-layer Cathode E-Beam Deposition, Thin Films, Surface Morphology, Surface Roughness, Open Circuit Voltage, Short Circuit Current

\section{Introduction}

Organic Solar Cells (OSCs) has attracted much interest of the researchers because of their high throughput, low-cost solution phase processing [1-5]. But, before OSCs can be commercialized practical limitations of OSCs such as low power conversion efficiency (PCE) that results from the low open-circuit voltage $\left(\mathrm{V}_{\mathrm{OC}}\right)$, short-circuit current $\left(\mathrm{J}_{\mathrm{SC}}\right)$ and fill factor $(\mathrm{FF})$ and limited operational lifetime must be overcome. The cathode of OSCs plays a crucial role of collecting electron. The efficiency of solar cell is a big factor. Historically, conventional solar cells were built from inorganic materials such as silicon. Although the efficiency of such conventional solar cells is high, very expensive materials and energy intensive processing techniques are required. New ways of manufacturing solar cells that can scale up to large volumes and low cost are required. A broad range of solar cell technologies are currently being developed including organic solar cell, dye-sensitized nanocrystalline photo electrochemical solar cells, polymer/fullerene bulk heterojunctions, small molecule thin films and organic-inorganic hybrid devices.

Organic solar cells have been the cheap alternatives for conventional silicon solar cells. An Organic solar cell consists of organic materials. Organic materials are inexpensive easily processable and their functionality can be tailored by molecular design and chemical synthesis.

Theoretically the efficiency of an organic solar cell can be increased by several ways. One such approach is to use buffer layer. The present study rationalizes the information spread in the literature concerning the use and role of buffer layers in organic solar cells. Usual device structures include buffer layers, both at the anode and at the cathode interface, mainly to favour charge collection and extraction, but also to improve the 
device's overall performance. Buffer layers are actually essential for achieving highly efficient organic solar cells.

Optical properties of $\mathrm{LaF}_{3}$ structures attract a lot of interest currently due to their application perspectives of Lanthanum Fluoride $\left(\mathrm{LaF}_{3}\right)$ is a highly refractive layer material and high transparency. $\mathrm{LaF}_{3}$ is also used as the diffusion barrier for $\mathrm{Al}$ into the photoactive polymer. In this background e-beam evaporate a very thin layer of $\mathrm{LaF}_{3}$ as a buffer layer to enhance the performance of the cell has been investigated. By varying the thickness of $\mathrm{LaF}_{3}$ the band gap can be tuned therefore the absorption range can be tailored. We observed that absorption decreased with the increased of $\mathrm{LaF}_{3}$ film thickness. The optimum layer thickness of $\mathrm{LaF}_{3}$ may be up to $3 \mathrm{~nm}$.

$\mathrm{LaF}_{3} / \mathrm{Al}$ cathode has been increased cell performance compare to the normal structure. $\mathrm{LaF}_{3} / \mathrm{Al}$ cathode annealed at $150^{\circ} \mathrm{C}$ for 20 minutes and showed better result than without annealing samples.

Two types of OSCs were fabricated \& investigated

1. ITO+PEDOT + P3HT-PCBM+Al

2. ITO+PEDOT+P3HT-PCBM+ $\mathrm{LaF}_{3}$ (various layer thickness) $+\mathrm{Al}$

\section{Experimental}

Thin films are thin material layers ranging from fractions of nanometer to several micrometers in thickness. There are various techniques for depositing thin film depending on the type of materials and thickness of layer to be deposited. In this thesis work Electron beam evaporation technique was used to deposit ITO (Anode), $\mathrm{LaF}_{3}$ and $\mathrm{Al}$ (Cathode). In this research, Edwards E-306 vacuum coating unit was used for depositing ITO, $\mathrm{LaF}_{3}$ and Al. In this research VTC-100 spin coater was used to deposit hole transport layer and photo active layer. OSCs were fabricated with a configuration of common sandwiched structure of ITO/PEDOT/P3HT: PCBM/LaF3-Al as shown in figure1. Readymade blend of P3HT and PCBM at 1:1 ratio and PDOT were bought from Sigma-Aldrich Chemie GmbH Steinheim, Germany. The OSC fabrication began with the deposition of ITO on a properly cleaned glass substrate. ITO thin films were deposited on a glass substrate at room temperature by electron beam evaporation technique using an Edwards E 306, UK. The deposition rate was $1.094 \mathrm{~nm} / \mathrm{s}$ at a beam current of $30 \mathrm{~mA}$ and chamber pressure of $2.5 * 10^{-5} \mathrm{mbar}$. Commercially available ITO powder (99.99\% pure) obtained from Inframat Advanced Materials, USA, was used as the evaporation source material. First the PEDOT:PSS (Hole transport material) polymer blend was coated on ITO by spin coating. The principle of spin coating is to apply a solution on the substrate, which is tightly held by vacuum pump. Then the substrate begins to spin in an accelerated manner, so the extra amount of solvent is spinned off and a thin layer remains. After we have programmed VTC 100, it starts to spin with the specified parameters. On PDOT:PSS, P3HT:PCBM (Photoactive material) film was deposited again using spin coater. After deposition of PEDOT:PSS (hole transport layer), the samples were annealed in a thermal annealing furnace (carbolite $\mathrm{CWF} 12 / 13$ ) in air at $130^{\circ} \mathrm{C}$ for 2 minutes. The photoactive polymer blend was heated at $45^{\circ} \mathrm{C}$ for 20 minutes prior to application in order to become more homogeneous [12]. The thickness of film strongly depends on spin speed of the spin coater. Generally thickness of film decreases with increasing spin speed and vice-versa. After each steps the morphology of the deposited layers were investigated by Atomic Force Microscope. Atomic force microscope (AFM) of model (XE 70) park system was used to study the surface of the film. After deposition of P3HT: PCBM, the samples were annealed in a thermal annealing furnace in air at $130^{\circ} \mathrm{C}$ for 2 minutes. After annealing they were left to be cooled naturally to the room temperature before deposition cathode. $\mathrm{LaF}_{3}$ thin films have been deposited on photoactive film by electron beam evaporation technique using an Edwards E-306 evaporator. Commercially available $\mathrm{LaF}_{3}$ powder $(99.99 \%$ pure) obtained from Chameleon Reagent and was used as the evaporation source material. For $\mathrm{LaF}_{3}$ the deposition rate was $0.33 \mathrm{~nm} / \mathrm{s}$ at a beam current of $30 \mathrm{~mA}$ and chamber pressure of $2.5^{*} 10^{-5} \mathrm{mbar}$. Finally, $\mathrm{Al}$ was evaporated on $\mathrm{LaF}_{3}$ by E-beam evaporator at a beam current of $20 \mathrm{~mA}$ and chamber pressure of $2.5^{*} 10^{-5} \mathrm{mbar}$.

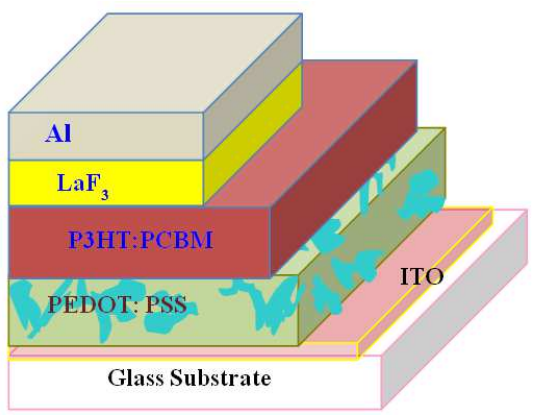

Figure 1. Schematic structure of an OSC with LaF 3 modified Al cathode.

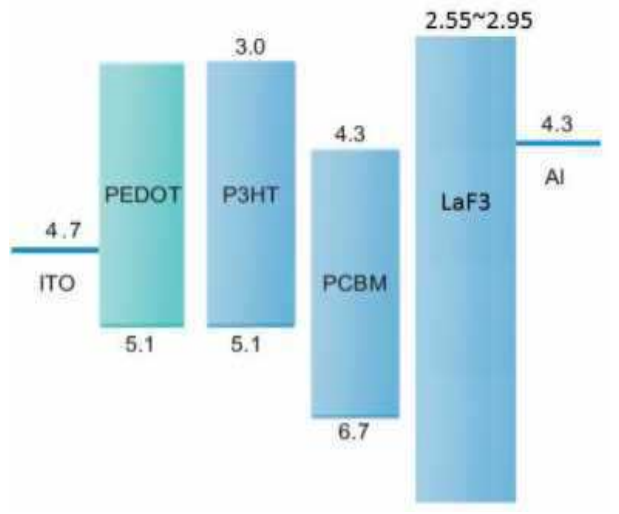

Figure 2. Energy diagram with $\mathrm{LaF}_{3}$ buffer layer [13].

The expected energy diagram is shown in Figure 2. Previously reported values were used for the energy levels of the Figure by adjusting to the present work. The energy diagram has been shown in flat-band conditions, i.e., without any band bending due to transfer of charge carriers between materials upon contact. As can be seen from Figure 2, energy barrier exist near the semiconductor-metal interface. Electrons are transported to $\mathrm{Al}$, and holes are transported to an ITO- coated substrate. Due to increased electrical field the electrons can tunnel through very thin $\mathrm{LaF}_{3}$ layer efficiently. Again, $\mathrm{LaF}_{3}$ film is an electrical 
insulator and due to its exceptionally large surface polarization thin $\mathrm{LaF}_{3}$ layer is expected to decrease the surface potential of the $\mathrm{Al}$ cathode and thus the effective work function, resulting in favorable electron extraction. These are all in good consistence with the obtained enhancement in $\mathrm{J}_{\mathrm{SC}}$ and $\mathrm{V}_{\mathrm{OC}}$. $\mathrm{LaF}_{3}$ layer can be also expected to block holes because of its ionization potential of $12.4 \mathrm{eV}$, which is much larger than that of PCBM $(6.3 \mathrm{eV}) . \mathrm{LaF}_{3}$ has a high electron affinity that is also expected to enhance electron extraction from PCBM and blocks holes as a result probability of radiative recombination is greatly improved. Moreover, recombination at the metal/polymer interface can be avoided as the $\mathrm{LaF}_{3}$ layer separates the recombination zone from the metal electrode. Due to the formation of an interface dipole at the surface of metal electrode generated by the thin layer of $\mathrm{LaF}_{3}$ and pointing toward the $\mathrm{Al}$ surface, the work function of metal electrode would be lowered.

\section{Results \& Discussion}

The surface morphology for different annealed temperature of ITO films was studied by AFM. Figure 3 shows the 3D-AFM image of the ITO/glass sample. The roughness of these films has been investigated by AFM. Roughness of these films increased with the increment of annealing time. The roughness has been found $\mathrm{rms}$ roughness $=1.639 \mathrm{~nm}$ and average roughness $=1.334$ for as deposited film. The surface morphology for hole transport layer was studied by AFM. Figure 4 shows the 3D-AFM image of the hole transport layer on ITO coated glass sample. The average roughness was found $0.842 \mathrm{~nm}$ and $\mathrm{rms}$ roughness found $1.139 \mathrm{~nm}$. The poly (3-hexylthiophene) (P3HT) and [6, 6]-phenyl C61-butyric acid methylester (PCBM) blends is one of the promising organic solar cell materials. The surface morphology of photoactive layer was studied by AFM. The roughness of photoactive layer has been found average roughness $0.235 \mathrm{~nm}$ and rms roughness $0.402 \mathrm{~nm}$. The roughness of intermediate layer (in our case $\mathrm{LaF}_{3}$ ) of bilayer cathode is very important as the P3HT:PCBM layer will be deposited on intermediate layer ( $\mathrm{LaF}_{3}$ layer). Very rough surface may lead to a bad electrical interface between the P3HT:PCBM blend. Figure 6 shows the surface morphology of the $\mathrm{LaF}_{3}$ layer as observed by an Atomic force Microscope (AFM).

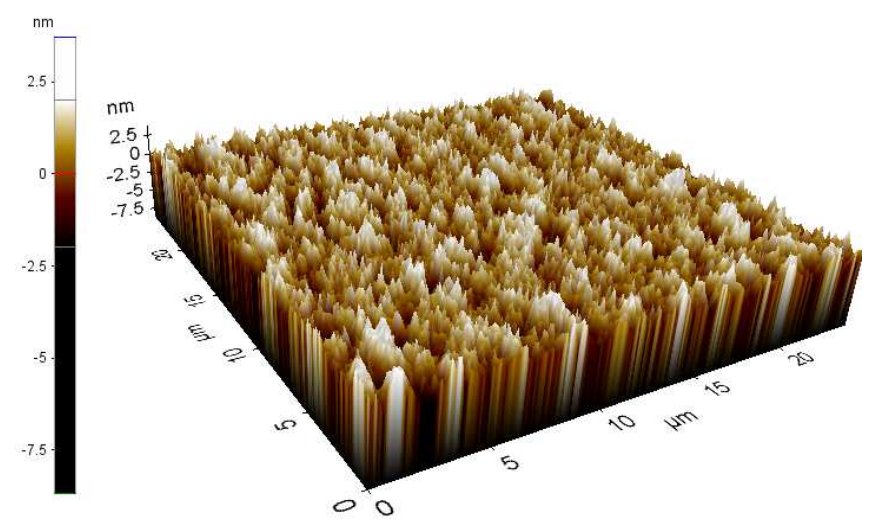

(a)
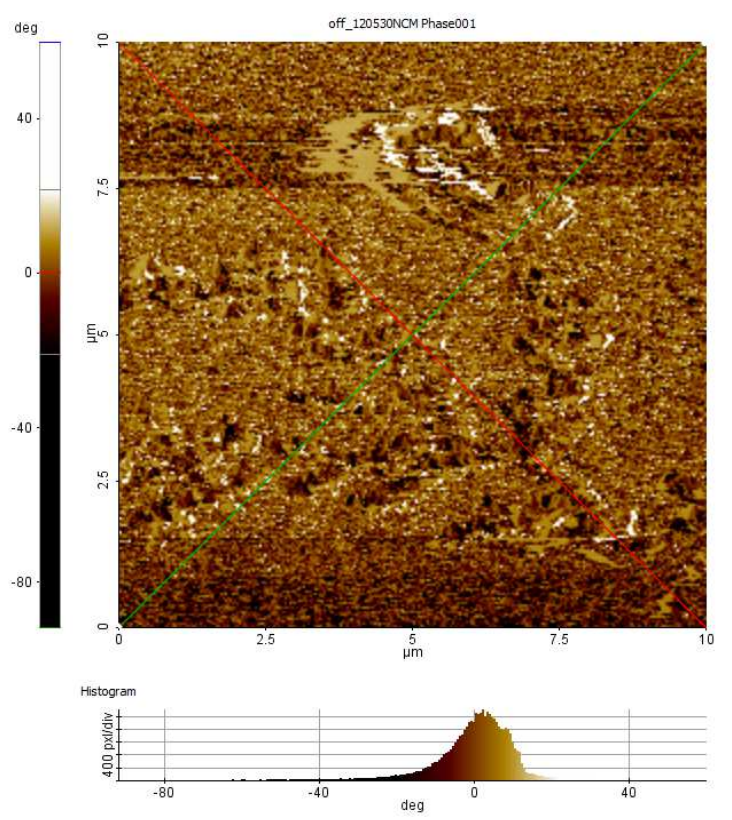
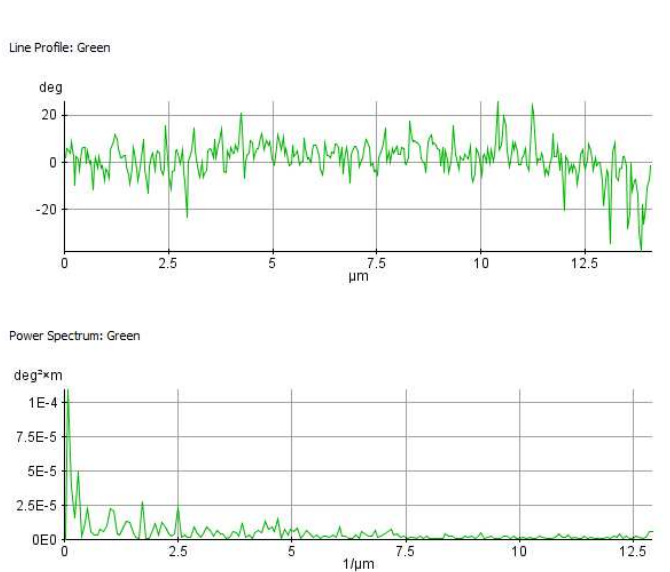

Line Histogram: Green

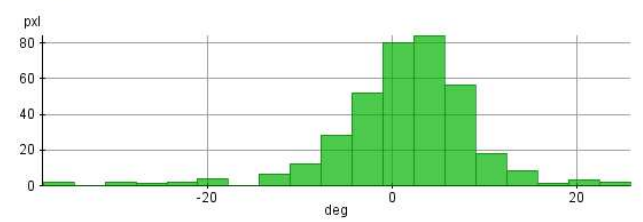

(b) 

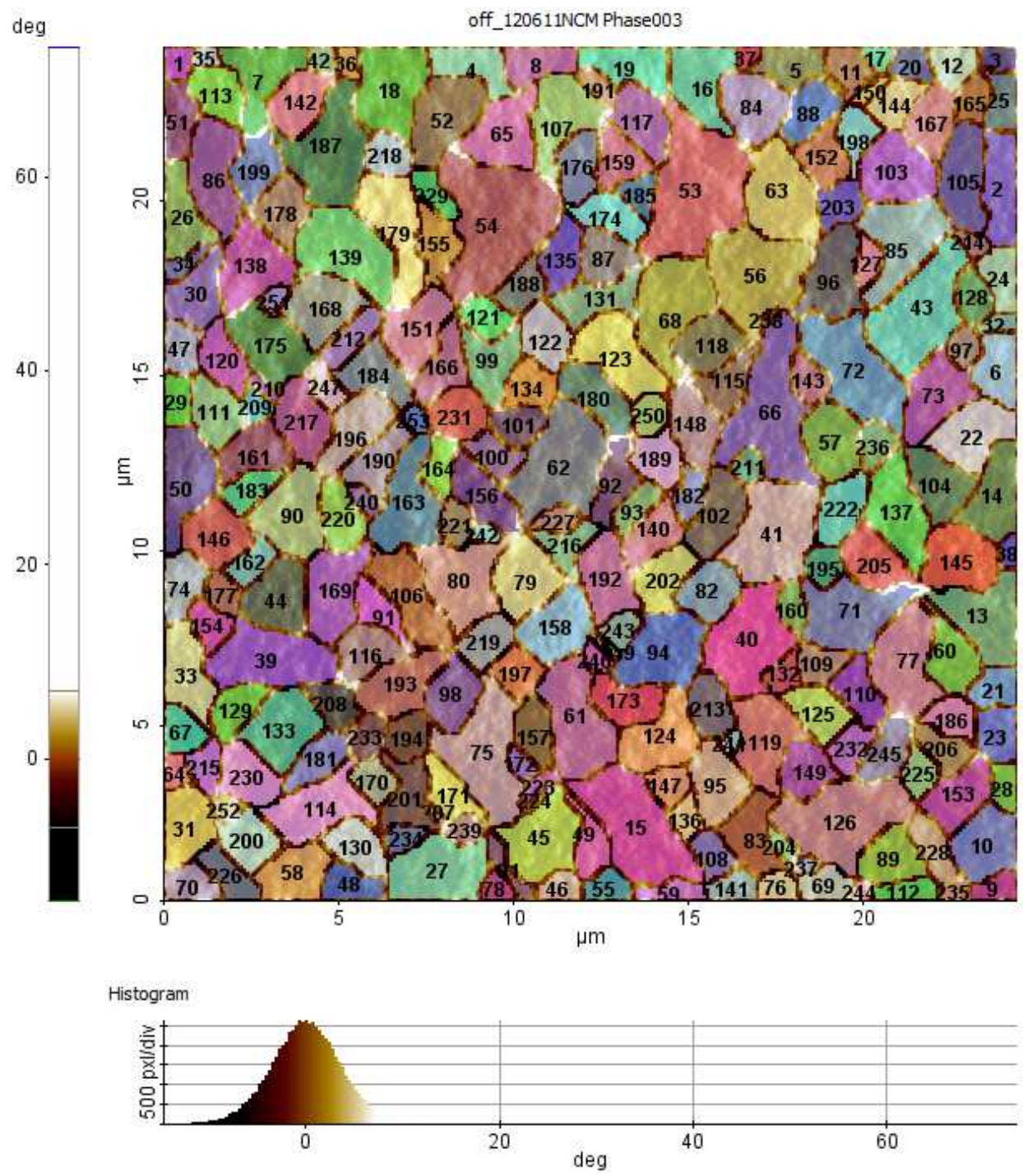

(c)

Figure 3. (a) Surface morphology of as deposited ITO film (b) line profile of ITO film (c) grain phase.

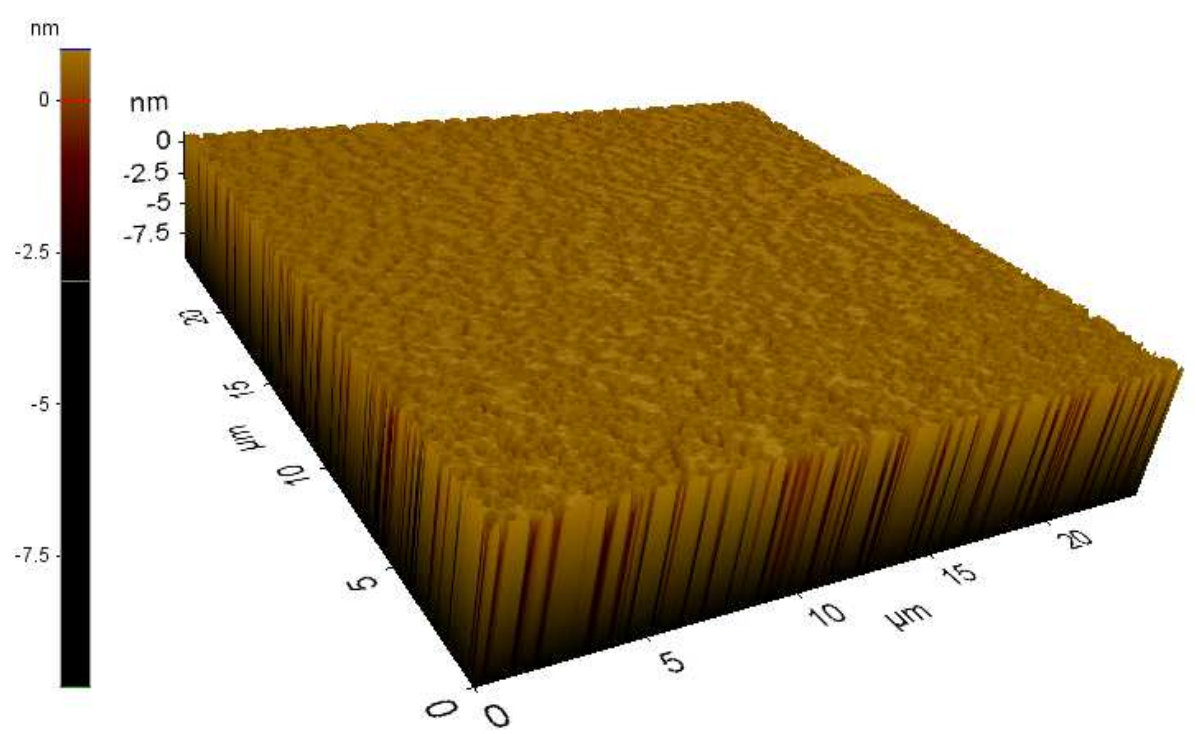

(a) 

with Lanthanum Fluoride Thin Layer

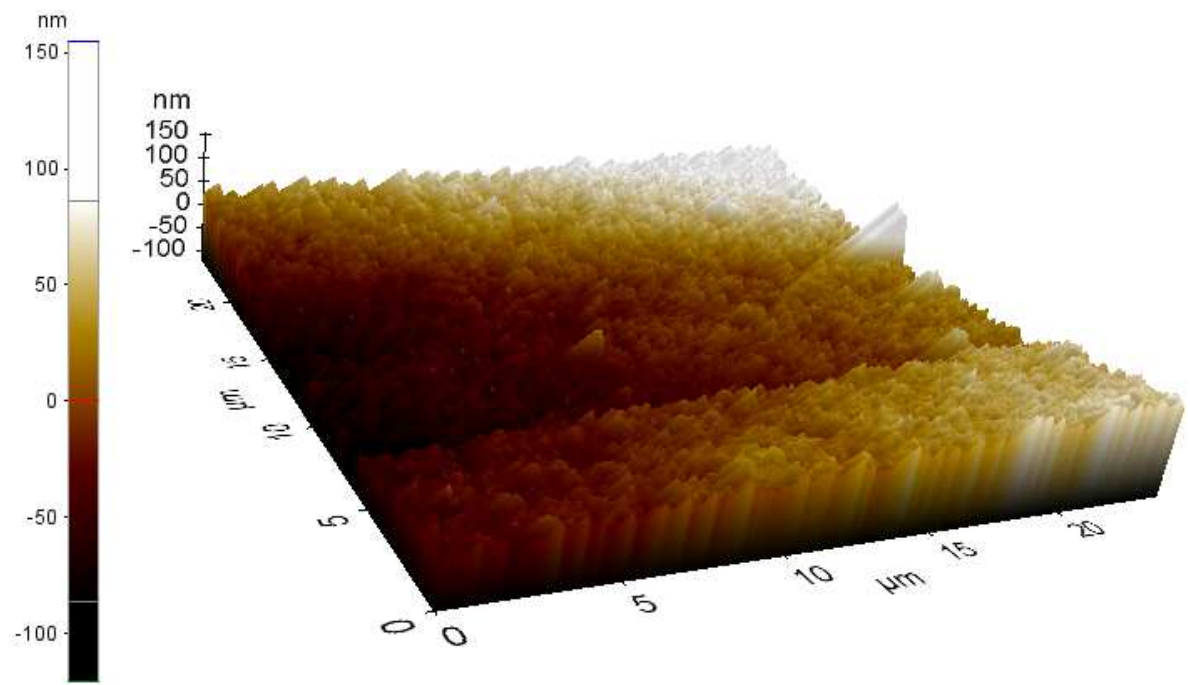

(b)

Figure 4. Surface morphology of hole transport layer (a) Amplitude (b) Topography.

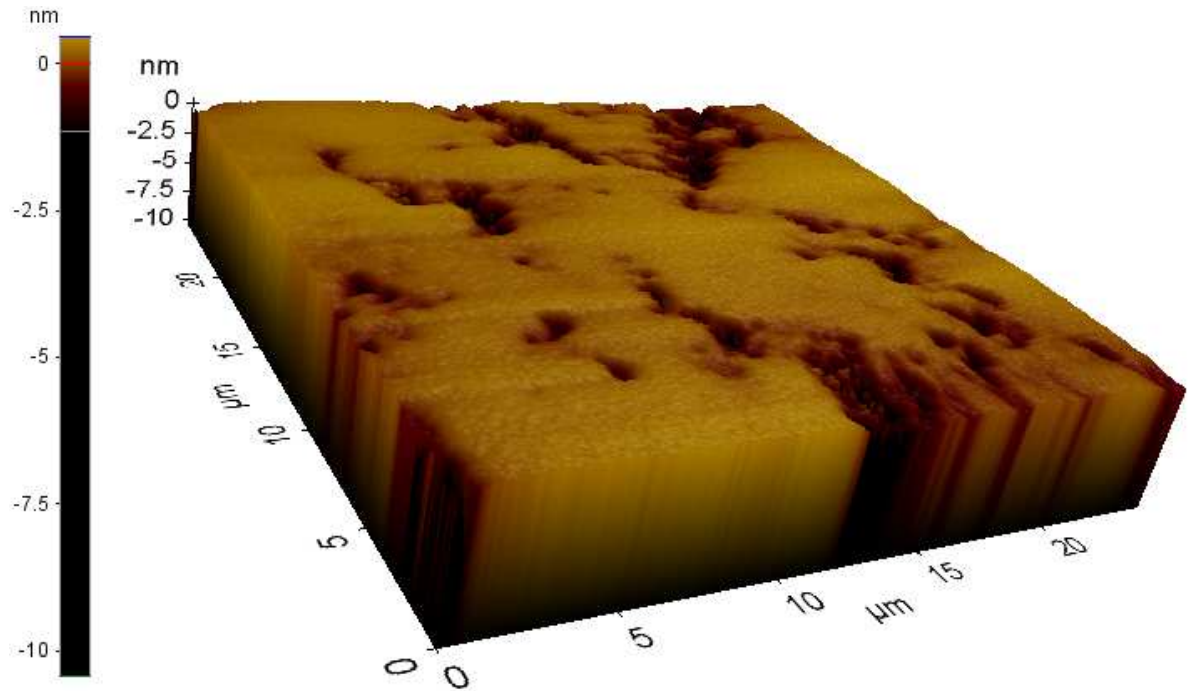

(a)

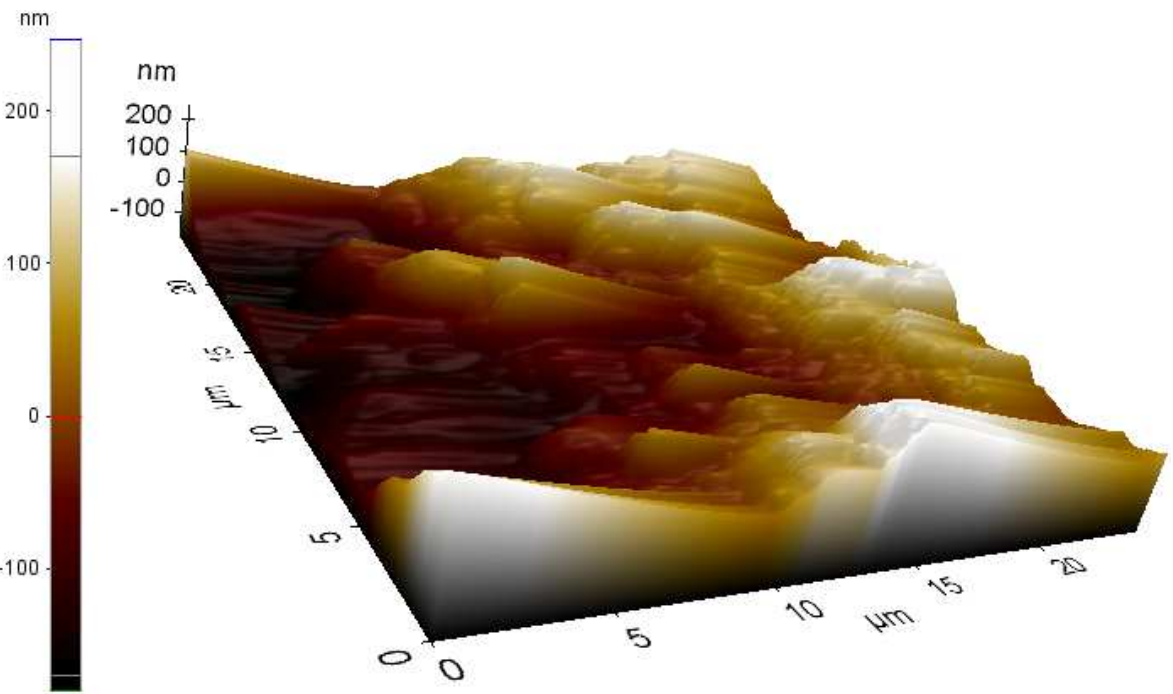

(b)

Figure 5. Surface morphology of photoactive layer (a) amplitude (b) topography. 


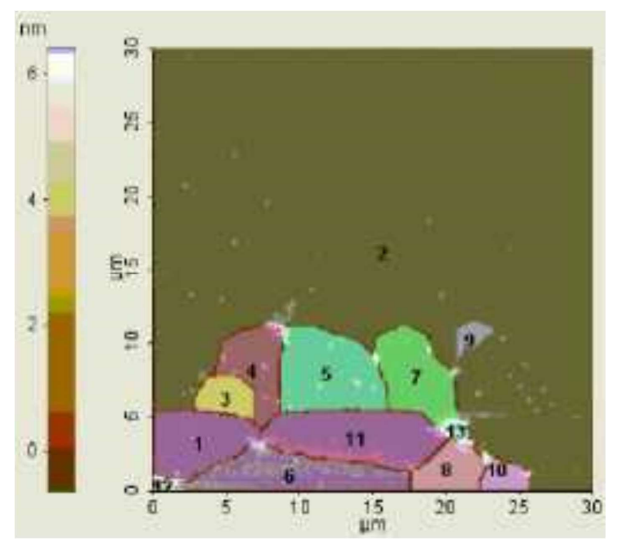

Figure 6. Grain size of three different layers: PDOT:PSS layer (3, 4, 5, 7, 9) and P3HT:PCBM layer $(1,11,6,8,10)$.

The average roughness of $\mathrm{LaF}_{3}$ layer has been found to be $0.0147 \mathrm{~nm}$. As can be seen from the figure 6 an amorphous $\mathrm{LaF}_{3}$ was obtained by e-beam deposition. The $\mathrm{LaF}_{3}$ layer was found to be like a single grain (grain\#2) having no grain boundary features. The roughness and grain-boundary less layer will certainly provide a very good electrical interface.
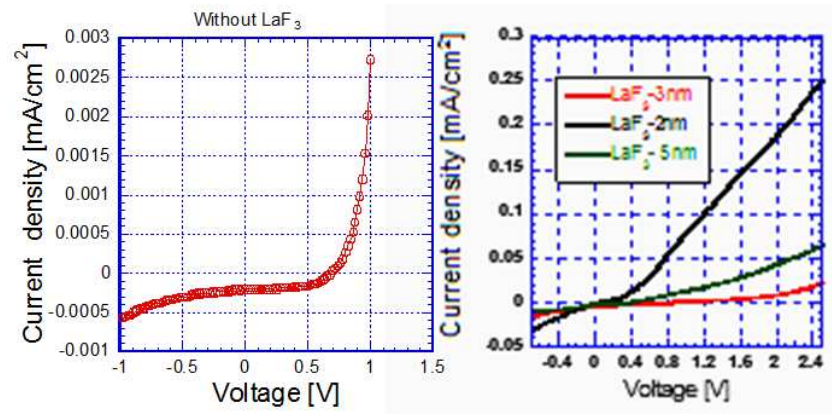

Figure 7. J-V characteristics of fabricated OSC.

Figure 7 shows the J-V characteristics of the fabricated OSC. Figure 8 shows the open circuit voltage $\left(\mathrm{V}_{\mathrm{O}}\right)$ and short circuit current density $\left(\mathrm{J}_{\mathrm{SC}}\right)$ as a function of $\mathrm{LaF}_{3}$ layer thickness. $\mathrm{V}_{\mathrm{oc}}$ and $\mathrm{J}_{\mathrm{SC}}$ increases for the $\mathrm{LaF}_{3}$ thickness of $3 \mathrm{~nm}$. However, reduction of $\mathrm{V}_{\mathrm{oc}}$ and $\mathrm{J}_{\mathrm{SC}}$ is observed for the higher $(>3 \mathrm{~nm}) \mathrm{LaF}_{3}$ layer thickness. These results indicates that the optimum thickness of $\mathrm{LaF}_{3}$ is $3 \mathrm{~nm}$. It is important to investigate the physical mechanism of the reduction of $\mathrm{V}_{\mathrm{oc}}$ and $\mathrm{J}_{\mathrm{SC}}$ for the higher thickness of $\mathrm{LaF}_{3}$.

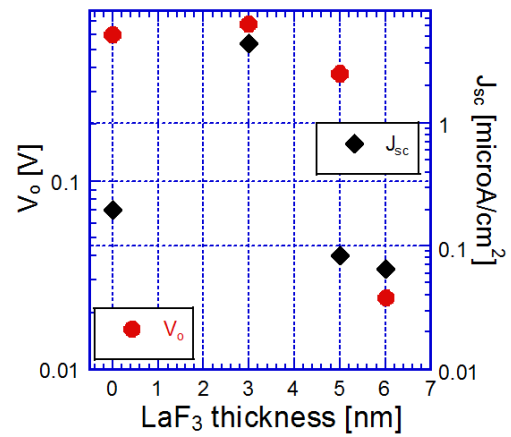

Figure 8. Voc and JSc as a function of LaF $\mathrm{F}_{3}$ thickness.

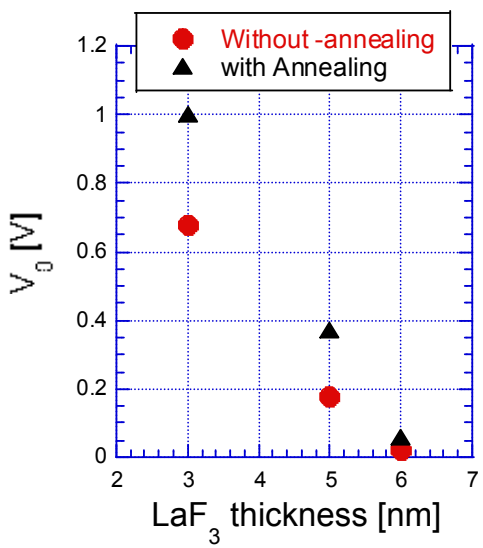

Figure 9. Effect of annealing on open circuit voltage.

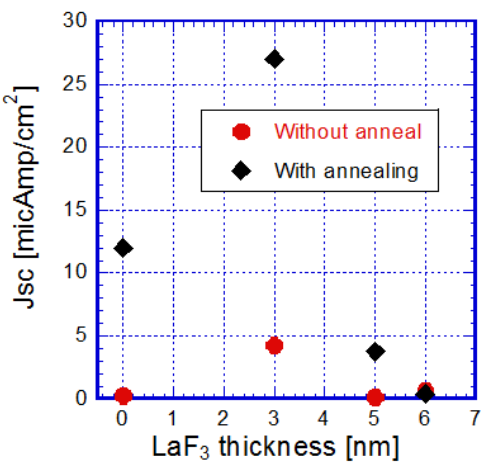

Figure 10. Effect of annealing on short circuit current density.

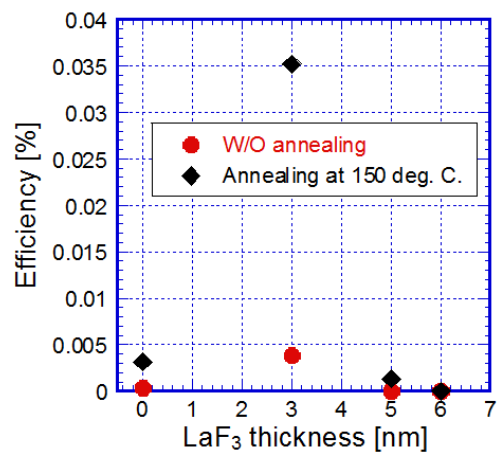

Figure 11. Effect of annealing on efficiency.

The J-V characteristics of the designed organic solar cells were studied under forward and reverse bias conditions in the dark and under 1.5 AM light. J-V characteristics were measured by KEITHLEY 2400 source meter. From figure 7 we see that reverse current density decreases with the increased thickness of $\mathrm{LaF}_{3}$. The maximum was for $2 \mathrm{~nm}$ and the minimum was for $6 \mathrm{~nm}$. The open circuit voltage for $2 \mathrm{~nm}$ $\mathrm{LaF}_{3} / \mathrm{Al}$ cathode was very poor. An open circuit voltage of $0.68 \mathrm{~V}$ and a short circuit current density of $4.3 \mu \mathrm{A} / \mathrm{cm}^{2}$ were found for $3 \mathrm{~nm} \mathrm{LaF} / \mathrm{Al}$ bi-layer cathode. As the I-V characteristics showed, the poor performance (reverse photocurrent) was due to the high series resistance of OSC, that might be due to our electrical connection from electrodes (ITO and Al) using silver paste. The effect of annealing on the performance of the cell has been also investigated. The 
post-fabrication annealed devices, with or without the $\mathrm{LaF}_{3}$ layer, exhibited higher values of short-circuit current, open-circuit voltage and efficiency than those of similar devices annealed before depositing the $\mathrm{Al}$ metal. It was found that annealing at $150^{\circ} \mathrm{C}$ for 20 minutes provided the best result. The efficiency of OSC are shown as a function of $\mathrm{LaF}_{3}$ thickness in Figure 11. The overall power conversion efficiency was found to enhance several order than that of the conventional structure of OSC having only $\mathrm{Al}$ as the cathode.

The efficiency of OSC decreased with the increase thickness of $\mathrm{LaF}_{3}$ layer thickness. The efficiency has been obtained too much poor that might be due to the series resistance of OSC increased when we made wire connection by using copper tape. From figure 11, it is clear that the efficiency of OSC has been increased by using $\mathrm{LaF}_{3} / \mathrm{Al}$ electrode than that of normal structure.

\section{Conclusion}

$\mathrm{LaF}_{3} / \mathrm{Al}$ bi-layer cathode has been fabricated and tested for P3HT: PCBM-based organic solar cells. The influence of $\mathrm{LaF}_{3}$ thickness on solar cell performance was studied. This research investigated a novel approach of inserting very thin buffer layer of $\mathrm{LaF}_{3}$ between the $\mathrm{Al}$ cathode and photoactive polymer to enhance the performance of conventional organic solar cell (OSC). The experimental results without any doubt indicated substantial increase in the short-circuit current density and open circuit voltage of the conventional OSC. The effect of annealing on the performance of the cell has been also investigated. The post-fabrication annealed devices, with or without the $\mathrm{LaF}_{3}$ layer, exhibited higher values of short-circuit current, open-circuit voltage than those of similar devices annealed before depositing the Al metal. It was found that annealing at $150^{\circ} \mathrm{C}$ for 20 minutes provided the best result. The overall power conversion efficiency was found to enhance several order than that of the conventional structure of OSC having only $\mathrm{Al}$ as the cathode. Although the conversion efficiency was very poor probably due to very high series resistance of the whole structure, it can be concluded that the approach of inserting a buffer layer of $\mathrm{LaF}_{3}$ would enhance the performance of conventional organic solar cell. The experimental results indicate that $\mathrm{LaF}_{3} / \mathrm{Al}$ bi-layer cathode can be used to enhance the performance of organic solar cells.

\section{References}

[1] C. J. Brabec, S. Gowrisanker, J. J. M. Halls, D. Laird, S. Jia and S. P. Williams, Polymer-fullerene bulk-heterojunction solar cells, Adv. Mater, 22 (2010) 3839-3856.

[2] M. Helgesen, R. Sondergaard and F. C. Krebs, Advanced materials and processes for polymer solar cell devices, J. Mater. Chem., 20 (2010) 36-60.

[3] J. Peet, M. L. Senatore, A. J. Heeger and G. C. Bazan, The Role of Processing in the Fabrication and Optimization of Plastic Solar Cells, Adv. Mater, 21 (2009) 1521-1527.

[4] H. B. Yang, Q. L. Song, C. M. Li and Z. S. Lu, New architecture for accurate characterization of the behavior of individual sub-cells within a tandem organic solar cell, Energy Environ. Sci., 1 (2008) 389-394.

[5] T. Ameri, G. Dennler, C. Lungenschmied and C. J. Brabec, Organic tandem solar cells: A review, Energy Environ. Sci., 2 (2009) 347-363.

[6] Ching-Chun Chang, et al "Effects of cathode buffer layers on the efficiency of bulk-heterojunction solar cells", Appl. Phys. Lett, 96 (2010) 263506-263508.

[7] Tang, CW.; Albrecht, AC. "Photovoltaic effects of metalchlorophyll-a-metal sandwich cells"J.Chem.Phys.62 .6 (1975). 2139-2149.

[8] O'Regan, B.; Gratzel, M. "A low-cost, high-efficiency solar cell based on dye-sensitized colloidal TiO2 films." Nature 353 (1991) 737-740.

[9] C. J. Brabec, J. A. Hauch, P Schilinsky, and C. Waldauf, MRS Bull. 30, 50 (2005).

[10] R. A. J. Janssen, J. C. Hummelen, and N. S. Sariciftci, MRS Bull. 30, 33(2005).

[11] P. Peumans, A. Yakimov, and S. Forrest, J. Appl. Phys. 93, 3693 (2003).

[12] H. Spangaard and F. Krebs, "A brief history of the development of organic and polymeric photovoltaics," SOLAR ENERGY MATERIALS AND SOLAR CELLS, vol. 83, pp.125-146, (2004).

[13] Frederik et al. Polymeric Solar Cells: Materials, Design, Manufacture. DEStech Publications, Inc., Lancaster, Pennsylvania, (2010). 